Elsevier Editorial System(tm) for Renewable \& Sustainable Energy Reviews Manuscript Draft

Manuscript Number: RSER-D-15-00308

Title: Energy Performances of Double-Skin Façades in Temperate Climates: A Systematic Review and Meta-Analysis

Article Type: Review Article

Keywords: Double Skin Façade; Operational Energy Reduction; Heating and Cooling Loads; Natural Ventilation; Embodied Energy.

Corresponding Author: Mr. Francesco Pomponi, MSc

Corresponding Author's Institution: Faculty of Science and Engineering - University of Brighton

First Author: Francesco Pomponi, MSc

Order of Authors: Francesco Pomponi, MSc; Poorang Piroozfar, PhD; Ryan Southall, PhD; Philip Ashton, $\mathrm{PhD}$

Abstract: Double Skin Façades (DSFs) are applied in both new and existing buildings, especially in temperate climates. Research in this area is steadily growing; however, there is a lack of conclusive results in available literature about energy performances related to the DSF, thus limiting a better and more informed application of this technology in the Architecture Engineering and Construction (AEC) sector. This paper systematically reviews more than 50 articles which have dealt with the energy related performance of DSFs in temperate climates and provide a meta-analysis of the numerical findings published in the studies examined. Energy related figures are presented separately for embodied and operational energy. Specifically, the operational energy end-uses taken into account are heating, cooling, lighting, and ventilation. Numerical results in the literature are normalised and expressed in form of percentage of maximum energy reduction/increment compared to a base case (e.g. a single skin case) used as a reference in the corresponding studies. Such an approach is meant to provide a reliable comparison of published figures. Key façade parameters (DSF spatial configurations, cavity width and ventilation), building parameters (orientation and climatic areas) and the methodological approaches used in the reviewed studies were deployed as clustering criteria. Several clustering criteria present extremely spread values, indicating the necessity to further investigate, understand, and attempt to reduce such high discrepancies in operational energy performances. Additionally, and more importantly, almost no information exists on DSFs life cycle energy figures, highlighting an important gap that requires further research.

Suggested Reviewers: Mohamad Kiani PhD

Principal Sustainability Consultant, Baily Garner LLP

mohamadrezakiani@gmail.com

Dr Kiani has extensive experience in sustainability in the construction industry. Additionally, his PhD thesis dealt with the environmental impacts of glazed facades which is a part of the review paper here submitted.

Abdullahi Ahmed PhD

Senior Lecturer, Civil Engineering, Architecture and Building, Coventry University ab0393@coventry.ac.uk 
Dr Ahmed's research deals with building performance evaluation, building simulation, and renewable energy. Additionally, his PhD thesis is about thermal modelling of sustainable buildings. Most of the studies here reviewed dealt with thermal modelling of DSFs, hence his choice.

Roberto Lamberts PhD

Professor, Civil Engineering, Federal University of Santa Catarina

roberto.lamberts@ufsc.br

Opposed Reviewers: Kenneth Ip PhD

Principal Lecturer, School of Environment and Technology, University of Brighton

k.ip@brighton.ac.uk

Dr Ip has co-supervised earlier stages of this research and could therefore be biased and recognise the writing style and figures used. 


\title{
Energy Performances of Double-Skin Façades in Temperate Climates: A Systematic Review and Meta-Analysis
}

\section{Authors Information:}

Mr Francesco Pomponi ${ }^{(1)}$, PhD candidate, corresponding author - f.pomponi@brighton.ac.uk

Dr Poorang Piroozfar ${ }^{(1)}$, Senior Lecturer - a.e.piroozfar@brighton.ac.uk

Dr Ryan Southall ${ }^{(2)}$, Senior Lecturer - r.southall@brighton.ac.uk

Dr Phil Ashton ${ }^{(1)}$, Principal Lecturer-p.ashton@brighton.ac.uk

${ }^{(1)}$ Faculty of Science \& Engineering - School of Environment \& Technology

University of Brighton, Cockcroft Building, Lewes Road BN2 4GJ, Brighton UK

${ }^{(2)}$ Faculty of Arts \& Humanities - School of Architecture

University of Brighton, Mithras House, Lewes Road BN2 4GA, Brighton UK

\begin{abstract}
Double Skin Façades (DSFs) are applied in both new and existing buildings, especially in temperate climates. Research in this area is steadily growing; however, there is a lack of conclusive results in available literature about energy performances related to the DSF, thus limiting a better and more informed application of this technology in the Architecture Engineering and Construction (AEC) sector. This paper systematically reviews more than 50 articles which have dealt with the energy related performance of DSFs in temperate climates and provide a meta-analysis of the numerical findings published in the studies examined. Energy related figures are presented separately for embodied and operational energy. Specifically, the operational energy end-uses taken into account are heating, cooling, lighting, and ventilation. Numerical results in the literature are normalised and expressed in form of percentage of maximum energy reduction/increment compared to a base case (e.g. a single skin case) used as a reference in the corresponding studies. Such an approach is meant to provide a reliable comparison of published figures. Key façade parameters (DSF spatial configurations, cavity width and ventilation), building parameters (orientation and climatic areas) and the methodological approaches used in the reviewed studies were deployed as clustering criteria. Several clustering criteria present extremely spread values, indicating the necessity to further investigate, understand, and attempt to reduce such high discrepancies in operational energy performances. Additionally, and more importantly, almost no information exists on DSFs life cycle energy figures, highlighting an important gap that requires further research.
\end{abstract}

Keywords: Double Skin Façade; Operational Energy Reduction; Heating and Cooling Loads; Natural Ventilation; Embodied Energy. 
Abbreviations:

$\begin{array}{ll}\text { ach } & \text { Air Changes per Hour } \\ \text { AEC } & \text { Architecture Engineering and Construction } \\ \mathrm{CO}_{2} & \text { Carbon Dioxide } \\ \mathrm{DGU} & \text { Double Glazed Unit } \\ \text { DSF } & \text { Double Skin Façade } \\ \text { ETTV } & \text { Envelope Thermal Transfer Value }\left(\mathrm{W} / \mathrm{m}^{2}\right) \\ \text { GHG } & \text { Greenhouse Gas } \\ \text { IGU } & \text { Insulated Glazed Unit } \\ \text { LCA } & \text { Life Cycle Assessment } \\ \text { SS } & \text { Single Skin } \\ \text { WWR } & \text { Window to Wall Ratio }\end{array}$

\section{Introduction}

The construction sector is responsible for around half of energy consumption, greenhouse gas (GHG) emissions, and depletion of natural resources worldwide [1]. Reducing its energy demand while also 'greening' its energy supplies through maximising the use of renewable energy should be of paramount importance. Without a resolute and concerted effort, carbon dioxide $\left(\mathrm{CO}_{2}\right)$ emissions related to worldwide energy consumption will double by 2050 [2]. Although much can be done by maximising the share of sustainable and renewable sources, it is also true that great opportunities lie in reducing demand. Given this context and providing the flexibility they can offer in design, Double Skin Façades (DSFs) can introduce significant benefits in reducing the energy demand of a building. DSF technology has been defined as one of the best options for an efficient management of the interaction between outdoor and indoor spaces [3]. Research on DSFs has been conducted in great details from a variety of perspectives, such as shading elements (including plants) in the cavity [4-7], airflow analysis and prediction [8-12], fire and smoke spreading issues [13-17], and natural ventilation [18-21]. Regardless of the drivers behind the decision to adopt DSF technologies-which can range from aesthetic reasons to more technical ones e.g. providing thermal comfort through passive cooling/heating, energy saving and reduction of GHG emissions seem to have always been amongst the main arguments for such decisions. Interestingly enough, a broad and systematic review of energy performance related to DSFs is still missing. This paper aims to fill such a gap, with a specific focus on temperate climates. A reduction of energy loads is also expected to turn into economic savings, which reinforce the need to better understand the energy reduction potential of DSFs. Although some monetary figures do exist [22], they can vary greatly and fall beyond the scope of this review. This paper builds on the knowledge capital of existing reviews already published on DSFs [3, 23-26]. Specifically, this research has used a systematic approach to review DSF energy performance, and has conducted a meta-analysis of the examined literature to normalise and present numerical findings in order to determine if significant trends could be mapped to assist DSF practitioners and academics alike.

To do so, a total of 247 articles matching initial search keywords were retrieved and examined carefully. Out of those, 55 were found fit for purpose for this review, and therefore investigated in greater details and used in this analysis. Selection of papers was carried out using the following criteria: 
(1) it had to address and assess energy-related figures associated with DSF, either related to DSF while in use - i.e. the operational energy - or the embodied energy, that is related to all lifecycle stages other than the operation phase $[1,27-29]^{1}$;

(2) with respect to operational energy, it had to present a base case against which the results could be compared in order to understand the comparative performance of DSFs, to enable to assess variations in the energy increment or reduction;

(3) it had to refer to, or be set in, moderate or temperate climates, considered as where there is a distinct demand for heating in winter and cooling in summer;

(4) it had to be published within the last 20 years.

To further clarify the climatic areas, selected studies have been then classified and clustered according to the Köppen-Geiger climate classification [31]. The details of the coding system for the climatic areas can be found in Peel et al. [31]. In the selection of studies, greater consideration has been given to journal articles. However, some conference publications have also been taken into account, since they presented results of experimental investigations or came from key researchers and/or leading practitioners in the field.

\section{Defining Dimensions and Essential Concepts of DSFs}

Existing definitions of DSFs are many and, to some extent, far between [33-37]. For the purpose of this study:

A glazed double skin façade is a hybrid system made of an external glazed skin and the actual building façade, which constitutes the inner skin. The two layers are separated by an air cavity which has fixed or controllable inlets and outlets and may or may not incorporate fixed or controllable shading devices.

The cavity may either act as a thermal buffer zone, as a ventilation channel or, more often, as a combination of the two. It may be naturally or mechanically ventilated, and vary in width and height. All these cavity parameters contribute to the defining dimensions of a DSF. The width is generally used to distinguish between narrow and wide cavities. Such a distinction is extremely important with regard to both operational and embodied energy. For the former, narrower air spaces may significantly influence air flow and air velocity whereas for the latter wider cavities often imply a higher amount of construction materials which, in turn, increase the embodied energy of the DSF. Although some numerical figures to distinguish between the two do exist [38], there is no general agreement upon such classification, and in this paper:

- Narrow cavity is when the width is up to $40 \mathrm{~cm}$; and

- Wide cavity is when the width exceeds $40 \mathrm{~cm}$.

The $40 \mathrm{~cm}$ limit is determined by the minimum width required to grant access to the cavity for maintenance purposes. The height of the cavity is used to define what here is referred to as the spatial configuration of the DSF. The types pioneered by Oesterle et al. [34], which have broadly been adopted by the others, include:

- Box windows (BW)

- Corridor (C)

${ }^{1}$ Other authors (see, e.g., Gustavsson and Joelsson [30]; Buyle et al. [32]) consider as embodied energy only the energy related to the production and construction phases. 
- Shaft box (SB), and

- Multi-storey (MS)

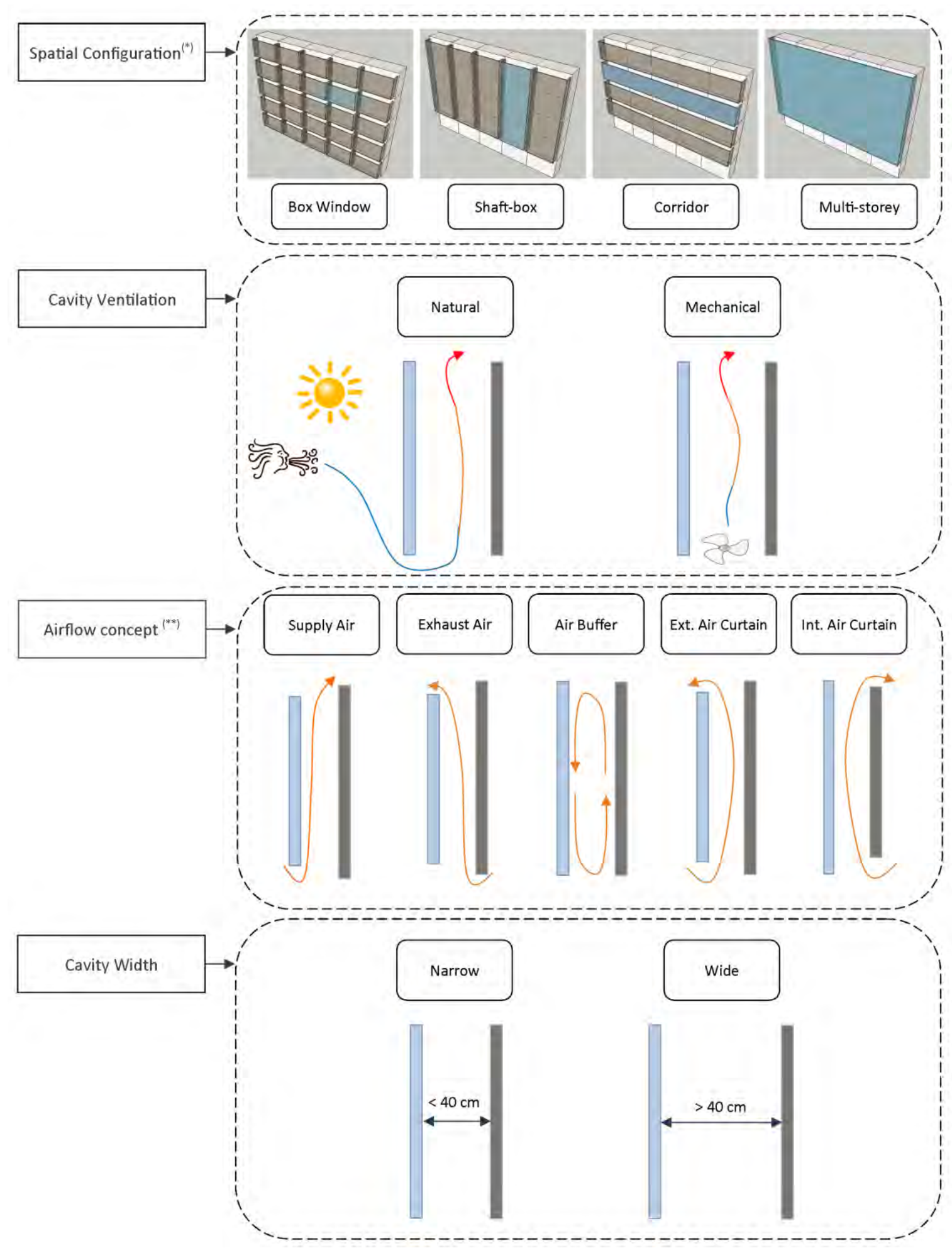

Figure 1 - Classification of DSFs ${ }^{\left.-{ }^{*}\right)}$ image courtesy of Sabrina Barbosa [22] $-{ }^{\left({ }^{* *}\right)}$ names of the airflow concepts are after Haase et al. [40] 
In addition to these, the Belgian Building Research Institute [39] adds a fifth type called 'Louvers Façade' whose outer skin is composed of transparent rotating louvers that, when closed, are capable of relatively good airtightness. Other classifying dimensions of a DSF involve the origin of the airflow [40] and its destination [40,41], which eventually define the airflow concepts as summarised by Haase et al. [42]. All these key defining elements are grouped into the classification of DSFs given in Figure 1.

The natural ventilation in a DSF is driven by two main forces related to:

- Pressure differences caused directly by wind action

- Pressure differences caused by thermal buoyancy ${ }^{2}$

The former happens as when wind hits a building two main faces of a building can be identified: the windward and the leeward side. Areas on the windward side are characterised by a positive pressure which pushes the air into or against the building. Areas on the leeward side have a negative pressure which results in a suction of the air out or away from the building [43]. Regarding the latter, thermal buoyancy occurs when hot air rises and cool air sinks. More specifically, air density changes when temperature changes. Warmer air occupies a greater volume than cooler air. Therefore it is lighter than cold air per unit of volume. The pressure difference due to the thermal buoyancy is expressed by Eq. 1 [34]:

$$
\Delta p_{t h b}=\Delta \rho \cdot g \cdot \Delta h \cdot \Delta T_{m}
$$

Equation 1 - Pressure differences due to thermal buoyancy in a DSF

Where:

- $\Delta \rho$ is the air density change due to the temperature change $\left[\mathrm{kg} / \mathrm{m}^{3}\right]$

- $g$ is the acceleration due to the gravity force $\left[\mathrm{m} / \mathrm{s}^{2}\right]$

- $\Delta \mathrm{h}$ is the actual height of the chimney [m]

- $\Delta \mathrm{T}_{\mathrm{m}}$ is the mean excess temperature [K]

As shown in the formula, the chimney effect depends upon the temperature difference between internal and external air, and the height of the column of air. This clarifies how significant the thermal buoyancy is in a DSF and why naturally ventilated DSFs are often found with multi-storey configurations. In the mechanically ventilated DSFs, ventilation is achieved by mechanical means, i.e. fans, usually installed in the cavity. Such a straightforward formula should not mislead and imply simplicity in DSFs behaviour which is hardly the case. To the contrary, DSF is a complex technology with many intertwined heat transfer mechanisms and fluid dynamic phenomena [23, 44].

\footnotetext{
2 Thermal buoyancy is also commonly referred to as stack or chimney effect, being it the principle which drives the conventional chimney stack. The three terms are, therefore, synonyms in the DSF context.
} 
Figure 2 - Cross section of a DSF and the adjacent indoor space showing the complexity of heat transfer mechanisms and fluid dynamic phenomena by Høseggen et al. [44]

Such a complexity has been represented thoroughly by Høseggen et al. [44] (Figure 2) and partially helps understand why energy performances related to DSFs are so varied. More specifically, the partitioning of the cavity with its divisions and obstructions; the solar radiation and the way it is influenced by shading devices and their position within the cavity; the convection regimes and airflow resistances; the frictional resistance of the materials of the inner and outer skins and of the obstructions in the cavity and their corresponding heat transfer coefficients; and cavity openings and vertical temperature gradient-all contribute to influence the DSF performance [44]. Often, a specific DSF is a unique combination of all these elements hence the difficulty in achieving consistent and agreed figures on DSFs energy performance.

\section{Embodied Energy Figures}

Research questions regarding life-cycle energy of DSFs, in general, and their embodied energy, in particular, firstly appeared nearly 20 years ago [45]. Still, the call for Life Cycle Assessment (LCA) of DSFs remain largely unanswered and only few attempts exist that aimed at addressing embodied energy figures and life cycle impacts holistically.

Wadel et al. [46] adopted a simplified LCA in the design of building skins with the specific focus on a modular 'unitised' double skin façade in 2013. The façade is made of hybrid profiles of recycled aluminium and laminated timber, a uniquely produced insulated glass with variable solar factor, and opaque enclosures formed of tempered glass, recycled aluminium, recycled carpet boards, sheep wool as insulation, cellular vapour barrier, and recycled cellulose fibre plaster board [46]. The figures assessed throughout the study are embodied energy per area of façade $\left(\mathrm{MJ} / \mathrm{m}^{2}\right)$, and $\mathrm{CO}_{2}$ emissions $\left(\mathrm{kg} \mathrm{CO}_{2} / \mathrm{m}^{2}\right)$, where the functional unit is $1 \mathrm{~m}^{2}$ of façade with a useful lifespan of 50 years. In the best case scenario, the façade is capable of $50 \%$ energy consumption and $\mathrm{CO}_{2}$ emissions reduction 
compared to conventional modular façade. Overall embodied values for the best configuration of the façade are $2273.08 \mathrm{MJ} / \mathrm{m}^{2}$ for the energy consumption, and $178.64 \mathrm{~kg} \mathrm{CO} / \mathrm{m}^{2}$ on the carbon dioxide emissions side. In terms of lighting and thermal energy, although results are preliminary, suggested savings are around $34 \%[46]$.

In the same year, de Gracia et al. [47] conducted a cradle-to-grave LCA of a ventilated double skin façade (VDSF) with phase change materials (PCM) in the cavity. Their LCA utilises the Eco-Indicator 99 (EI99), an impact assessment method based on endpoints where results from different impact categories are normalised and brought together to contribute to a final, single, cumulative score for the product/process under examination. The functional units used are the entire two cubicles constructed in Spain, one with a VDSF and the other as a reference. The lifetime of the cubicles is considered to be 50 years, although sensitivity analyses for 75- and 100-year lifetime scenarios were also carried out [47]. Overall results indicate that the VDSF reduces the environmental impact by $7.5 \%$ over 50 years compared to the reference case. The endpoint assessment method El99 used in the study is useful to explain what the main damage categories are. However, it increases the difficulties in comparing and assessing results lacking clarity, for instance about embodied energy figures.

These contributions represent the only existing detailed studies on DSF life-cycle. Moreover, they refer to specific façade typologies, which are innovative products but do not represent the current practice of DSFs in the AEC industry. A less type-specific environmental impact assessment of office façades has been done by Kolokotroni et al. [48], where embodied energy and El99 have also been used as assessment methods and the DSF has been found to have the highest embodied energy $\left(2120 \mathrm{MJ} / \mathrm{m}^{2}\right)$ but the lowest endpoint score for both naturally-ventilated and air-conditioned offices [48]. A specific DSF configuration is just one among many other façade options they assessed for both naturally-ventilated and air-conditioned offices, and therefore there seems to be a trade-off between the depth and the breadth of the study.

The scarcity of embodied figures or, more specifically, life-cycle studies about DSFs may well be due to the greater share that operational energy tends to have when compared to embodied energy. In this respect, detailed LCA studies concluded that "optimization of operations phase performance should still be the primary emphasis for design, until it is evident that there is a significant shift in distribution of life-cycle burdens" [49, p. 1061]. However, due to increased efficiency in insulating materials and advancement of disciplines such as passive design, the balance between operational and embodied energy is changing significantly, and environmental burdens are shifting. In this regard, recent research suggests a major role of façade elements, which constitute "a substantial volume of the total consumption of materials used in a building and the need for maintenance of the façade [which] makes it especially interesting from a life cycle perspective" [50, p. 139]. Therefore, the focus on embodied energy and life-cycle energy performance of DSFs seems to be a growing area for further investigations.

\section{Operational Energy Performances}

Papers dealing with operational energy performances are reviewed in this section. This research has systematically reviewed four energy end-uses, namely heating, cooling, lighting, and ventilation, as those normally influenced by a building façade performance. It is important to note that, where multiple scenarios were assessed in a study, the result of interest for this paper was the 'best' case 
scenario to understand the maximum energy saving potential of the DSF. Similarly, when the DSF proved to increase energy consumption, the highest value has been considered. Additionally, type of the study, main orientation, cavity ventilation, DSF spatial configuration, cavity width, and presence of shading devices in the cavity are all parameters which have been considered and reviewed as well. A summary of the systematic review is shown in Table 1. In terms of types of study the three following categories have been identified and deployed throughout the paper:

(1) Mathematical, where results are obtained by means of equations to address and solve thermal and fluid-dynamic problems;

(2) Experimental, where findings result from laboratory activities or monitoring of real DSFs; and

(3) Simulation, where a Building Energy Simulation (BES) software tool (e.g. IES VE, Energy Plus, etc.) or a Computational Fluid Dynamic (CFD) software tool (e.g. Fluent, Flovent, etc.) have been utilised. 
Table 1 - Summary of the main studies reviewed

\begin{tabular}{|c|c|c|c|c|c|c|c|c|}
\hline Ref. & Location & Type of study & $\begin{array}{c}\text { Köppen- } \\
\text { Geiger zone }\end{array}$ & $\begin{array}{c}\text { Main } \\
\text { Orientation }\end{array}$ & Cavity Ventilation & $\begin{array}{l}\text { DSF Spatial } \\
\text { Configuration }\end{array}$ & Cavity width [m] & $\begin{array}{c}\text { Shading Devices in } \\
\text { the Cavity }\end{array}$ \\
\hline [55] & Belgrade, Serbia & Mathematical & $\mathrm{Cfb}$ & W & Natural & $\mathrm{C}$ & 0.6 & $\mathrm{~N}$ \\
\hline [67] & Tokyo & $\begin{array}{l}\text { Simulation, } \\
\text { Mathematical }\end{array}$ & $\mathrm{Cfa}$ & $\mathrm{S}$ & Mixed & MS & 2 & $Y$ \\
\hline [52] & Italy & $\begin{array}{l}\text { Experimental, } \\
\text { Simulation }\end{array}$ & $\mathrm{Cfa}$ & $\mathrm{S}$ & $\begin{array}{l}\text { Natural, } \\
\text { Mechanical }\end{array}$ & $\mathrm{C}$ & $0.3,0.5,0.7$ & $Y$ \\
\hline [72] & Venice, Italy & Simulation & $\mathrm{Cfa}$ & SW & Natural & MS & 0.65 & $\mathrm{~N}$ \\
\hline [79] & Florence & Mathematical & $\mathrm{Cfa}$ & $S$ & Natural & MS & $\begin{array}{c}0.07-0.15-0.25- \\
0.35\end{array}$ & $\mathrm{~N}$ \\
\hline [59] & Germany, Austria & Experimental & $\mathrm{Cfb}$ & $E, S, W$ & $\begin{array}{l}\text { Natural, } \\
\text { Mechanical }\end{array}$ & MS & N/A & $\mathrm{Y}$ \\
\hline [62] & Ankara, Turkey & Simulation & Csa & SW-NE & $\begin{array}{l}\text { Natural, } \\
\text { Mechanical }\end{array}$ & $\mathrm{MS}, \mathrm{SB}, \mathrm{C}$ & $\mathrm{N} / \mathrm{A}$ & $\mathrm{N}$ \\
\hline [66] & Instanbul, Turkey & Simulation & $\mathrm{Cfa}$ & $\begin{array}{l}41^{\circ} \mathrm{N} ; 28^{\circ} \mathrm{E} \\
\text { (the DSF wraps } \\
\text { the building) }\end{array}$ & Natural & MS & $\begin{array}{c}0.3-0.6-0.9-1.2 \\
-1.5\end{array}$ & $Y$ \\
\hline [56] & $\begin{array}{l}\text { Yongin, South } \\
\text { Korea }\end{array}$ & $\begin{array}{c}\text { Experimental } \\
\text { (monitoring), } \\
\text { Simulation }\end{array}$ & Dwa & $S$ & Natural & MS & 1 & $\mathrm{~N}$ \\
\hline [65] & Lab & Experimental & & $\mathrm{N}, \mathrm{S}, \mathrm{W}, \mathrm{E}$ & Natural & MS & 1.2 & $\mathrm{~N}$ \\
\hline [82] & $\begin{array}{l}\text { Stuttgart, } \\
\text { Germany }\end{array}$ & $\begin{array}{c}\text { Experimental } \\
\text { (laboratory and } \\
\text { monitoring), } \\
\text { Simulation }\end{array}$ & $\mathrm{Cfb}$ & SW, SE & $\begin{array}{l}\text { Natural, } \\
\text { Mechanical }\end{array}$ & BW & 0.5 & $\mathrm{Y}$ \\
\hline [80] & Barcelona, Spain & Mathematical & Csa & $S$ & Natural & BW & 0.1 & $Y$ \\
\hline [60] & Lab & $\begin{array}{l}\text { Experimental, } \\
\text { Simulation }\end{array}$ & & $S$ & $\begin{array}{c}\text { Natural, } \\
\text { Mechanical }\end{array}$ & BW & 0.15 & $Y$ \\
\hline [57] & Teheran, Iran & Mathematical & Bsk & W, S, SW & Natural & MS & 0.3 & $\mathrm{~N}$ \\
\hline [83] & Belgium & Simulation & $\mathrm{Cfb}$ & $\mathrm{S}$ & $\begin{array}{l}\text { Natural, and } \\
\text { Mixed }\end{array}$ & MS & 1.2 & $Y$ \\
\hline [58] & Belgium & Simulation & $\mathrm{Cfb}$ & $S$ & $\begin{array}{l}\text { Natural, and } \\
\text { Mixed }\end{array}$ & MS & 1.2 & $Y$ \\
\hline
\end{tabular}




\begin{tabular}{|c|c|c|c|c|c|c|c|c|}
\hline Ref. & Location & Type of study & $\begin{array}{c}\text { Köppen- } \\
\text { Geiger zone }\end{array}$ & $\begin{array}{c}\text { Main } \\
\text { Orientation }\end{array}$ & Cavity Ventilation & $\begin{array}{l}\text { DSF Spatial } \\
\text { Configuration }\end{array}$ & Cavity width [m] & $\begin{array}{c}\text { Shading Devices in } \\
\text { the Cavity }\end{array}$ \\
\hline [91] & Belgium & Simulation & $\mathrm{Cfb}$ & $\mathrm{N}, \mathrm{S}$ & Natural & MS & 1.2 & $\mathrm{Y}$ \\
\hline$[6]$ & Belgium & Simulation & $\mathrm{Cfb}$ & $\mathrm{N}, \mathrm{S}, \mathrm{W}, \mathrm{E}$ & Natural & MS & 1.2 & $Y$ \\
\hline [70] & Belgium & Simulation & $\mathrm{Cfb}$ & N-S, E-W & Natural & MS & 1.2 & $Y$ \\
\hline [92] & Belgium & Simulation & $\mathrm{Cfb}$ & $\mathrm{N}, \mathrm{S}$ & Natural & MS & 1.2 & Y \\
\hline [84] & $\begin{array}{l}\text { Prague, Czech } \\
\text { Republic }\end{array}$ & Simulation & $\mathrm{Cfb}$ & $\mathrm{S}$ & $\begin{array}{c}\text { Natural, } \\
\text { Mechanical }\end{array}$ & MS & 0.64 & $Y$ \\
\hline [44] & $\begin{array}{l}\text { Trondheim, } \\
\text { Norway }\end{array}$ & Simulation & Dfc & $\mathrm{E}$ & Mechanical & MS & N/A & $\mathrm{Y}$ \\
\hline [87] & $\begin{array}{c}\text { Germany (28 } \\
\text { different } \\
\text { buildings) }\end{array}$ & $\begin{array}{l}\text { Experimental } \\
\text { (monitoring) }\end{array}$ & $\mathrm{Cfb}$ & various & various & $\mathrm{MS}, \mathrm{SB}, \mathrm{C}, \mathrm{BW}$ & various & various \\
\hline [74] & $\begin{array}{l}\text { Ansan, South } \\
\text { Korea }\end{array}$ & $\begin{array}{c}\text { Experimental } \\
\text { (monitoring), } \\
\text { Simulation }\end{array}$ & $\mathrm{Cfa}$ & $E, W$ & Natural & MS & 0.5 & $Y$ \\
\hline [61] & Central Korea & Simulation & Dwa & $\mathrm{S}$ & Natural & MS & $0.3,0.6,0.9,1.2$ & Y \\
\hline [71] & $\begin{array}{c}\text { Ansan, South } \\
\text { Korea }\end{array}$ & $\begin{array}{c}\text { Experimental } \\
\text { (monitoring), } \\
\text { Simulation }\end{array}$ & $\mathrm{Cfa}$ & $\mathrm{SW}^{* *}$ & Natural & $\mathrm{C}$ & 0.5 & $Y$ \\
\hline [48] & UK & $\begin{array}{l}\text { Simulation, } \\
\text { Mathematical }\end{array}$ & $\mathrm{Cfb}$ & $N, S, E, W$ & $\begin{array}{c}\text { Natural and } \\
\text { Mixed }\end{array}$ & MS & 0.2 and 0.8 & $\mathrm{~N}$ \\
\hline [69] & London, UK & Simulation & $\mathrm{Cfb}$ & $\mathrm{S}$ & Natural & MS & w & $\mathrm{N}$ \\
\hline [68] & Brussels, Belgium & $\begin{array}{l}\text { Experimental } \\
\text { (monitoring) }\end{array}$ & $\mathrm{Cfb}$ & NE-SW & Mechanical & MS & 0.143 & $\mathrm{Y}$ \\
\hline [90] & $\begin{array}{l}\text { Dusseldorf, } \\
\text { Germany }\end{array}$ & Experimental & $\mathrm{Cfb}$ & NE/SW & Mixed & $\mathrm{C}$ & $0.9-1.4$ & $Y$ \\
\hline [53] & UK & N/A & $\mathrm{Cfb}$ & various & various & various & various & various \\
\hline [85] & UK & $\begin{array}{l}\text { Experimental, } \\
\text { Mathematical }\end{array}$ & $\mathrm{Cfb}$ & $S$ & Natural & $\mathrm{C}$ & Narrow $(0.1-0.3)$ & $\mathrm{Y}$ \\
\hline [77] & Crete, Greece & Simulation & Csa & SE-NW & Natural & MS & 1 & $\mathrm{Y}$ \\
\hline [54] & Denver, USA & N/A & $\mathrm{Cfa}$ & $\mathrm{N}-\mathrm{S}$ & Natural & MS & Narrow & $\mathrm{N}$ \\
\hline
\end{tabular}




\begin{tabular}{|c|c|c|c|c|c|c|c|c|}
\hline Ref. & Location & Type of study & $\begin{array}{c}\text { Köppen- } \\
\text { Geiger zone }\end{array}$ & $\begin{array}{c}\text { Main } \\
\text { Orientation }\end{array}$ & Cavity Ventilation & $\begin{array}{l}\text { DSF Spatial } \\
\text { Configuration }\end{array}$ & Cavity width [m] & $\begin{array}{c}\text { Shading Devices in } \\
\text { the Cavity }\end{array}$ \\
\hline [22] & Atlanta (US) & $\begin{array}{l}\text { Experimental, } \\
\text { Mathematical }\end{array}$ & $\mathrm{Cfa}$ & $S$ & Natural & BW & $\mathrm{N} / \mathrm{A}$ & $Y$ \\
\hline [73] & Germany & $\begin{array}{l}\text { Experimental } \\
\text { (monitoring) }\end{array}$ & $\mathrm{Cfb}$ & $E / W$ & Natural & MS & 0.5 & $Y$ \\
\hline [51] & Madrid, Spain & Mathematical & Bsk & $S$ & $\begin{array}{l}\text { Natural and } \\
\text { Mechanical }\end{array}$ & MS & 0.9 & $\mathrm{~N}$ \\
\hline [86] & $\begin{array}{c}\text { Budapest, } \\
\text { Hungary }\end{array}$ & Simulation & $\mathrm{Cfb}$ & W & Natural & MS & av. $600 \mathrm{~mm}$ & $Y$ \\
\hline [93] & Belgium & $\begin{array}{l}\text { Experimental, } \\
\text { Mathematical }\end{array}$ & $\mathrm{Cfb}$ & SW & $\begin{array}{l}\text { Natural and } \\
\text { Mechanical }\end{array}$ & BW & $\mathrm{N} / \mathrm{A}$ & $Y$ \\
\hline [40] & Belgium & $\begin{array}{c}\text { Mathematical, } \\
\text { Simulation }\end{array}$ & $\mathrm{Cfb}$ & $N, S, E, W$ & $\begin{array}{l}\text { Natural and } \\
\text { Mechanical }\end{array}$ & C, BW & $\mathrm{N} / \mathrm{A}$ & $Y$ \\
\hline [76] & Belgium & Simulation & $\mathrm{Cfb}$ & NE-SW & $\begin{array}{c}\text { Natural, } \\
\text { Mechanical }\end{array}$ & C, BW & $\mathrm{N} / \mathrm{A}$ & $Y$ \\
\hline [11] & France & Simulation & $\mathrm{Cfb}$ & $N / A$ & Mechanical & BW & 0.2 & $Y$ \\
\hline [89] & various locations & Simulation & various zones & various & various & various & various & various \\
\hline [78] & $\begin{array}{l}\text { Delft, The } \\
\text { Netherlands }\end{array}$ & $\begin{array}{l}\text { Experimental, } \\
\text { Simulation }\end{array}$ & $\mathrm{Cfb}$ & $S$ & $\begin{array}{c}\text { Natural, } \\
\text { Mechanical }\end{array}$ & BW & 0.6 & $Y$ \\
\hline [7] & $\begin{array}{l}\text { Delft, The } \\
\text { Netherlands }\end{array}$ & $\begin{array}{l}\text { Experimental, } \\
\text { Mathematical }\end{array}$ & $\mathrm{Cfb}$ & $\mathrm{S}$ & Mechanical & BW & $\mathrm{N} / \mathrm{A}$ & $Y$ \\
\hline [81] & Japan & $\begin{array}{l}\text { Experimental } \\
\text { (monitoring), } \\
\text { Mathematical }\end{array}$ & $\mathrm{Cfa}$ & W & Natural & C & 1.4 & $Y$ \\
\hline [88] & Brussels & $\begin{array}{l}\text { Simulation, } \\
\text { Experimental }\end{array}$ & $\mathrm{Cfb}$ & $E / W$ & Mixed & MS & 1.4 & $\mathrm{~N}$ \\
\hline [63] & Japan & $\begin{array}{l}\text { Experimental, } \\
\text { Mathematical }\end{array}$ & $\mathrm{Cfa}$ & E-W, N-S & Natural & $\mathrm{C}$ & 1.23 & $\mathrm{~N}$ \\
\hline [64] & Istanbul, Turkey & Mathematical & $\mathrm{Cfa}$ & $S$ & $\begin{array}{c}\text { Natural, } \\
\text { Mechanical, and } \\
\text { Mixed }\end{array}$ & $\mathrm{C}, \mathrm{MS}$ & $\mathrm{N} / \mathrm{A}$ & $\mathrm{N}$ \\
\hline [75] & London, UK & Simulation & $\mathrm{Cfb}$ & $S$ & Natural & MS & 0.9 & $Y$ \\
\hline
\end{tabular}




\subsection{Heating}

The reduction of heating loads is among the most widely used supporting arguments for a DSF in temperate climates. Solar radiation enters the closed cavity passing through the glass which transforms the radiation into heat.

The heat is then trapped in the cavity and warms up the air creating convectional airflow patterns (Figure 1 - Air Buffer). Such a working mechanism is already beneficial since it reduces heat losses through the inner skin of the building. Furthermore, where the quality of air is satisfactory, the warmer air in the cavity can also be supplied to indoor spaces (Figure 1 - Supply Air and Internal Air Curtain).

Such a reduction in heating load can then be enhanced by other façade parameters. For instance, Perez-Grande et al. [51] focused on thermal aspects related to glass selection concluding that appropriate glass choices can reduce the thermal load by up to $90 \%$. Baldinelli [52] showed that savings due to reduction in heating loads can be as high as $65 \%$ for a DSF compared to a fully glazed single skin façade. Similar results have also been achieved in broader contexts, i.e. the UK, when DSFs have been compared to advanced single skins [53]. Comparable findings in the UK have been reported by Kolokotroni et al. [48] who showed a $70 \%$ decrement in heating loads. Significant $50 \%$ and $40 \%$ reductions of heating loads have been found by Pappas [54] and Andjelkovic et al. [55] respectively, due to the greenhouse effect when DSFs are compared to single skin solutions. Similarly, results in this range have been obtained by Choi et al. [56] in Korea, Ghadamian et al. [57] in Iran, Gratia and De Herde [58] in Belgium, Blumenberg et al. [59] in Germany and Austria, and Fallahi et al. [60] in a lab-based experiment. It is worth mentioning that DSFs suggested significant energy savings, even within a renovation or refurbishment context, of $38 \%$ in case of a residential building studied by Kim et al. [61], and of $45 \%$ in an office building analysed by Cakmanus [62].

A second group of consistent results is within the $20 \%-30 \%$ reduction range. Such investigations span from field experiments in residential houses in Japan [63] to the use of DSFs in new buildings or as a renovation strategy for existing ones in Turkey [64]. In a comparative study about ETTV of a DSF and of a traditional double glazed installation, Chou et al. [65] observed a reduction of 32.9\% when the WWR equals to 0.5 . Similar numerical results are also achieved in studies more focused on comparisons between DSFs and single skin options [44, 66-70]. Comparable savings have been observed by $18.7 \%$ during winter months in Korea [71], by $20.5 \%$ in the restoration of industrial buildings in Italy [72], and by $18 \%$ in real monitoring of three DSF buildings in Germany [73].

More modest heating loads reduction (14.71\%) have been found by Kim et al. [74] where it is recommended to avoid the DSF to face east if enough solar radiation is to be received and a sufficient ventilation rate achieved. In a study on DSFs in different locations [75], a 7.47\% reduction has been found in the case of London. Likewise, DSF was found to be only $5 \%$ more efficient than a non-optimised IGU and an optimised IGU turned out to actually be more efficient than DSF [76]. In few cases DSFs underperformed single skin solutions. Saelens et al. [40] found that in the heating season the DSF requires $20 \%$ more energy than a traditional IGU. Similarly, another study suggests that the DSF is actually pejorative in terms of heating loads, with a value as significant as $28 \%$ [77]. The normalised data from the studies reviewed, in the form of percentage of heating loads reduction, are ranked from the highest to the lowest in Figure 3. 


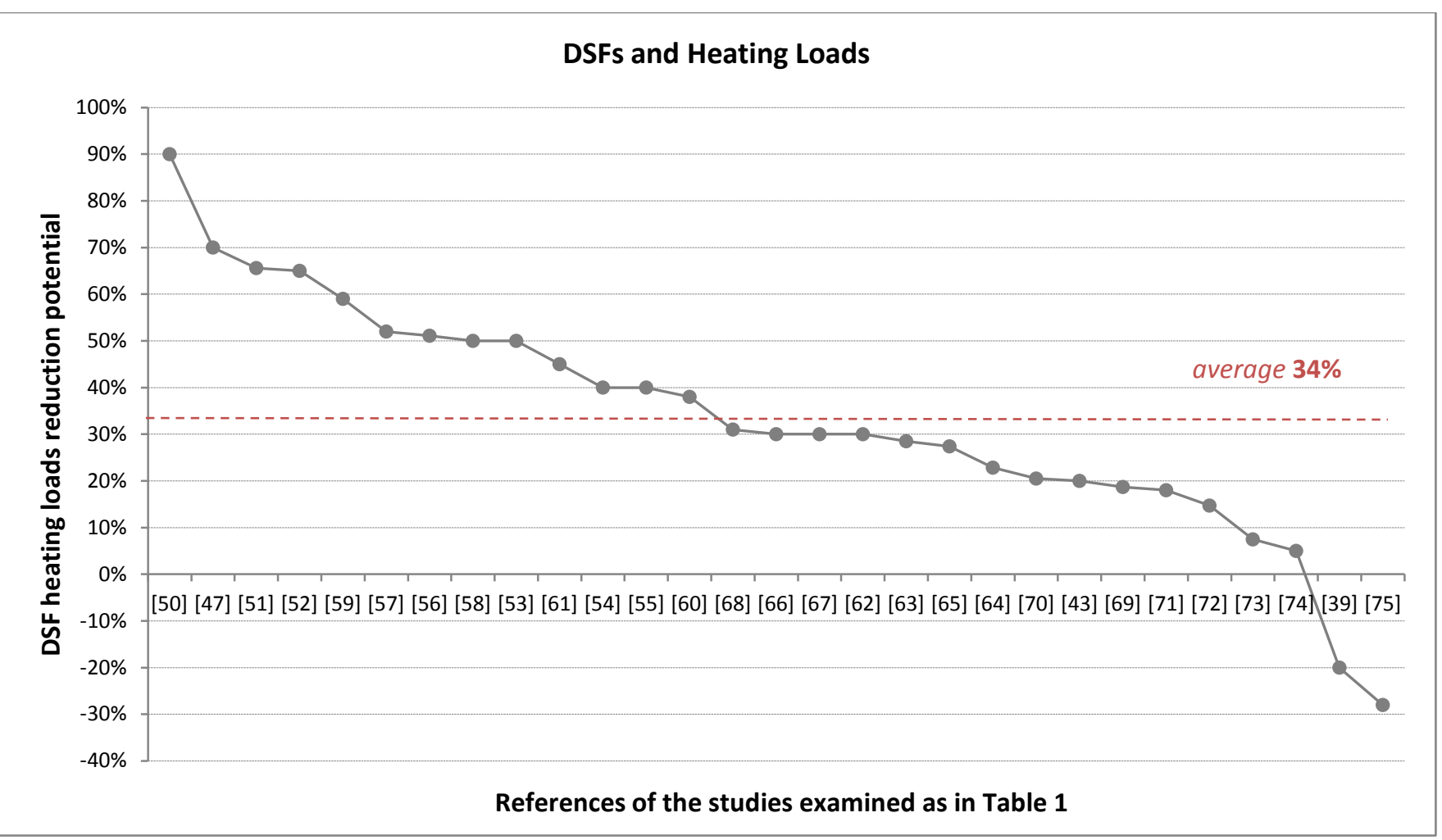

Figure 3 - Ranked maximum values of heating loads reduction attributable to a DSF in the studies examined

\subsection{Cooling}

Cooling savings attributed to DSF correspond either to the supply of fresh air with little or no help of mechanical means or the extraction of the heat from the occupied spaces through the stack effect (Figure 1 - Supply Air and Exhaust Air respectively). Additionally, even when indoor spaces have no ventilation onto the cavity, the DSF can still act as a natural fan which cools off the inner skin (Figure 1 - External Air Curtain). A particular advantage of the DSF is that all these working principles can also be applied at night due to the additional security that the second skin bears, thus allowing for a significant exploitation of night cooling strategies.

In this respect, Stec and van Paassen [78] investigated ventilation strategies and their potential to reduce energy consumption where both night cooling and natural ventilation are suggested to significantly cut back on cooling loads, with numerical results as high as $70 \%$. Even higher results of up to $93.3 \%$ are suggested when the performance of a DSF is compared against that of a fully glazed façade [52]. Similarly, reduction remains impressively high (86.6\%) when the comparison is against a conventional façade with a WWR of 0.5 [52]. From the practitioner side, Kragh reports numerical reductions within a 30\%-40\% range in two cases, one in the UK and one in Belgium [68, 69]. Similar findings show reductions of $37.8 \%$ in Iran [57] and $38 \%$ by in central Korea [61]. It is worth noting that the two cases that showed negative performance on heating loads, perform instead very well when cooling is considered with basically identical values of 31.9\% [77] and 32\% [40] respectively. Balocco [79] studied the influence of cavity width on the cooling potential of the DSF, finding that a cavity of $35 \mathrm{~cm}$ leads to the maximum reduction of 27.5\%. Faggembauu et al. [80] also evaluated the influence of different parameters, such as position of shading devices and low-e glazing, achieving a maximum reduction of $27 \%$ of indoor gains and cooling loads. In examining the energy performance of DSFs with thermal mass in the cavity, Fallahi et al. [60] obtained a $26 \%$ reduction in the case of a mechanically ventilated façade. Very similar experimental results have been achieved in Japan where a $25 \%$ reduction of solar heat gain of the indoor spaces was observed [81]. Numerical findings in such a range are also observed in European studies specifically focused on cooling issues [6, 82]. Cooling reduction potential of using plants as shading elements in the cavity points at a $19 \%$ decrement [7]. Findings from Kolokotroni et al. [48], Hensen et al. [83], and Xu and Ojima [63] all fall in the same range. The least significant reduction of cooling loads related to a DSF has been found to be of $9.5 \%$ by Ballestini et al. [72] where the energy savings potential of a multi-storey 
naturally ventilated DSF was evaluated for the rehabilitation of old industrial buildings in Italy. Finally, there is a case where DSF was actually found to worsen the cooling loads of the building with a $41 \%$ increment [70]. It should be noted that although the latter is the only case in which numerical results prove a worse situation cooling-wise, there 85]. Such a phenomenon also highlights summer indoor comfort issues related to DSFs. Empirical field studies on a large number of real buildings seem to indicate that DSFs can be slightly better than single skins in terms of thermal comfort [86] but such an aspect falls outside the scope of this review. Figure 4 shows normalised data from the papers reviewed for this study in the form of cooling loads percentage reduction - findings are ranked from highest to lowest.

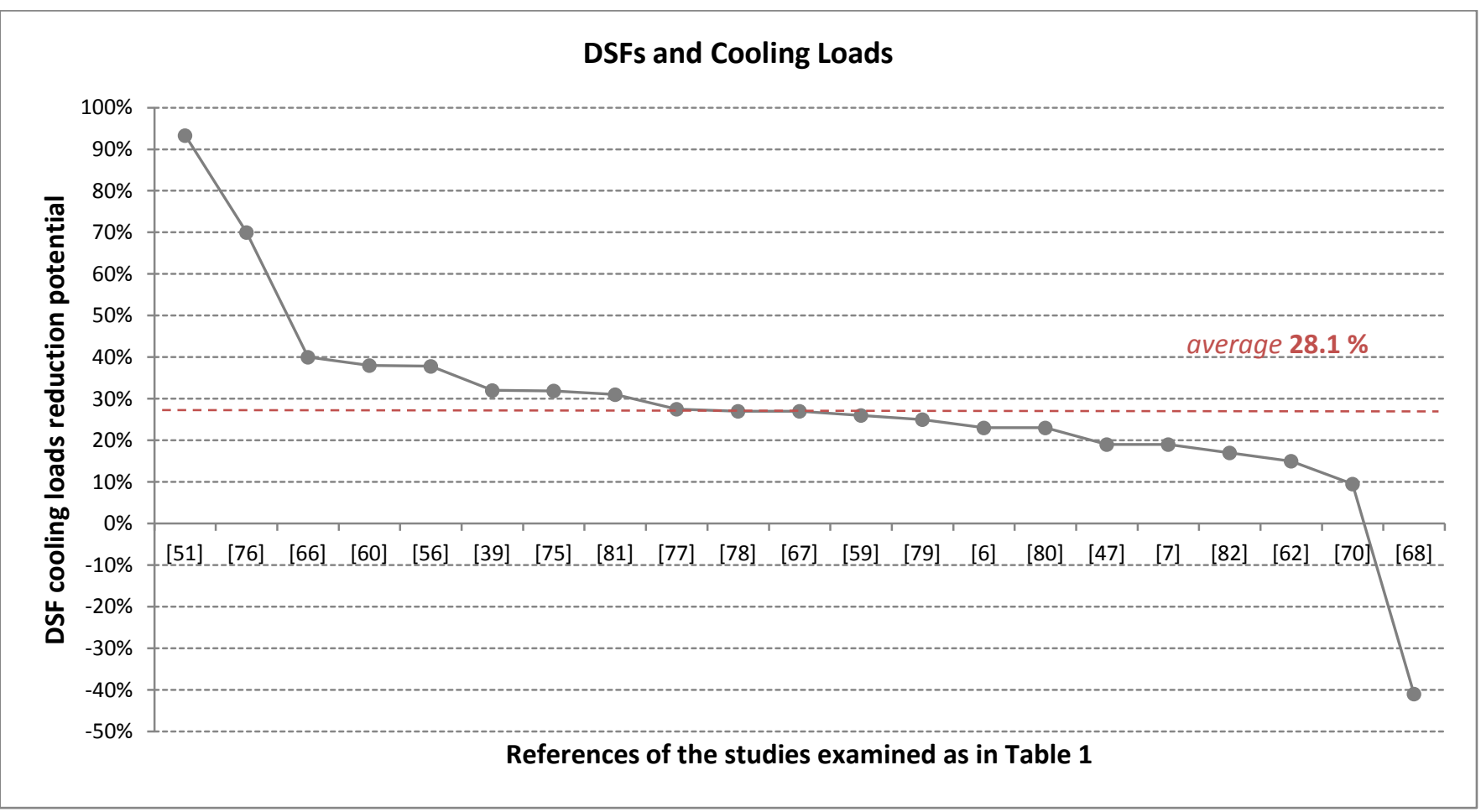

Figure 4 - Ranked maximum values of cooling loads reduction attributable to a DSF in the studies examined

\section{3 lighting}

Not many studies exist about the impact DSFs have on artificial lighting and/or daylighting. Viljoen et al. [87] investigated daylighting implications of refurbishing an existing office building in Brussels with a DSF with a cavity of $1.4 \mathrm{~m}$ equipped with walkways. The scenarios they assessed differ in walkways and sky conditions and, as a result, up to $64 \%$ of the floor area could be daylit for $50 \%$ of the year to 300 lux or more, and up to $80 \%$ of the area could be fully daylit for $35 \%$ of the year in a 9am to $5 \mathrm{pm}$ Monday to Friday working schedule assumption [87]. Quite to the contrary, Shameri et al. [88] investigated the daylighting performances of 12 DSF systems by means of IES VE and found that none of the DSF models meet the standard for indoor illuminance of at least 200 lux within $75 \%$ of the office floor area. Given such a small number of existing studies and the broad difference of their results, DSF's impact on energy consumption and GHG emissions pertaining to artificial lighting or otherwise potential savings due to daylighting cannot be verified until subject to further and broader investigations.

\subsection{Ventilation}

Despite having a major impact, ventilation is addressed very much in conjunction to cooling and very few studies have focused on it on its own. Here ventilation is considered as the possibility to supply fresh, good-quality air into the occupied spaces by through the DSF and it is reported in terms of percentage of the year during which the DSF can meet such expectation. In reporting findings from monitoring of real DSF buildings, Pasquay [73] provides evidence of the possibility to ventilate a building by means of a DSF for the full year. Promising results of $60 \%$ are 
also reported by Blumenberg et al. [59] and Lang and Herzog [89]. However, there are also less positive findings that suggest the need for mechanical means to ventilate the building for more than half a year $[71,78]$. The difficulty of ventilation via DSFs has been assessed also by Gratia and De Herde [90] who studied the effects of wind direction, building orientation, openings size, and cross vs. single-sided ventilation in a DSF prototypical building. However, in a later study [91], the same authors assess the feasibility to naturally ventilate a building through a DSF where they suggest that maximum attention has to be paid, at the design stage, to inlet openings [90, 91] and inlet temperatures [92] as key parameters.

\section{Normalised Data for Operational Energy}

Numerical findings from the studies reviewed in this paper have been normalised and presented as a percentage of reduction/increase in terms of operational energy consumption in comparison to a base case. Previous sections have highlighted that existing DSF studies in temperate climates chiefly vary according to:

- Spatial configuration of the DSF

- Width of the DSF

- Ventilation of the DSF

- Methodological approach to studying the DSF

- More specific climates within the broader spectrum of temperate or moderate climates

Therefore, these have been selected as the classifying criteria to cluster and present the normalised data. Box and whiskers plots, which have been previously successfully used to show normalised review data [93], are deployed to graphically present the clustered results in this study.

The legend chosen is shown in Figure 5. Due to the limited number of studies related to lighting, ventilation, and embodied energy, these plots are only provided for heating and cooling loads. Additionally, out of all DSF spatial configurations and climatic areas found in the studies only the most common ones have been reported, namely Multi-Storey (MS) and Corridor (C), and temperate hot (Cfa) and warm (Cfb) summers-respectively.

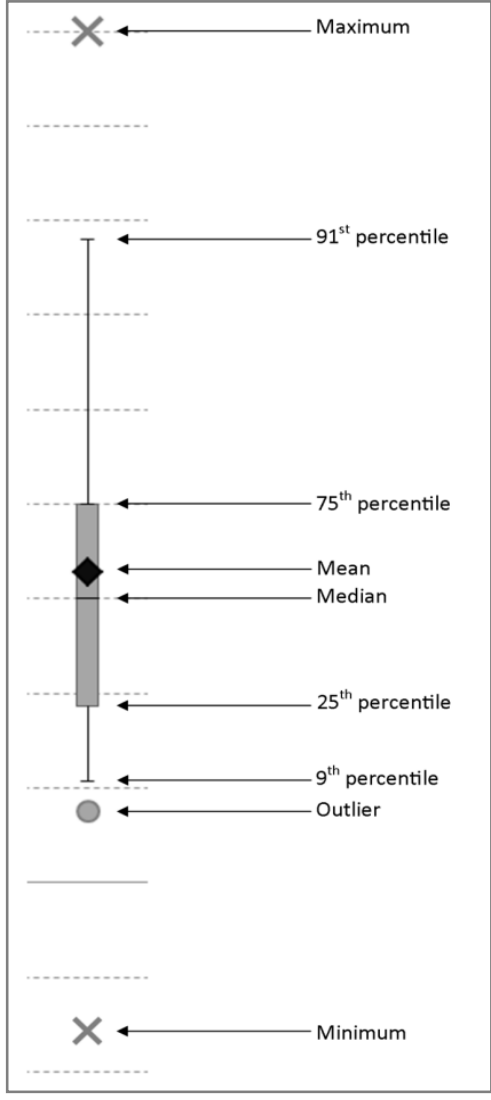

Figure 5 - Legend for the box and whiskers plots

\subsection{Heating Loads}

Figure 6 shows the box and whiskers plots for heating loads reduction potential.

Although data normalisation has been carried out to ensure that statistical comparison makes sense, it is important to bear in mind that every study has its own peculiarities and it would not be possible to fully account for all of them, e.g. variation in the glass types analysed. Nonetheless, such a meta-analytic representation can be helpful to identify existing trends and to disclose associations not yet detected. In this respect, it seems that simulation results are in line with experimental findings. Additionally, simulation has proven capable to assess cases in which the DSF has had an adverse effect to the building it was applied to. Quite to the contrary, mathematical and analytical approaches tend to overestimate the saving potential. In case of mixed methods results are more like those obtained from simulation.

Regarding cavity ventilation, mechanically ventilated cavities show an interquartile range much more limited compared to those naturally ventilated. This is not unexpected as mechanical means give greater control over ventilation in the cavity. However, the energy consumed by those fans nearly halves the maximum saving potential of mechanically ventilated cavities over naturally ventilated ones. Broader interquartile ranges are also observed for 
wide cavities and multi-storey spatial configurations. These two clusters are in fact the only two showing outliers that fall outside the $9^{\text {th }}-91^{\text {st }}$ percentile range. Such configurations are often found in combination with natural ventilation strategies which greatly rely on design effectiveness and weather conditions to work properly and these 1 two criteria could partially explain why results are so spread. However, more significant savings seem to be

6 achievable when a combination of the two strategies, i.e. mixed ventilation, is used, although this should be holistically evaluated from a life cycle perspective to take into account the augmented embodied energy that fans and their integration into the HVAC system bear.

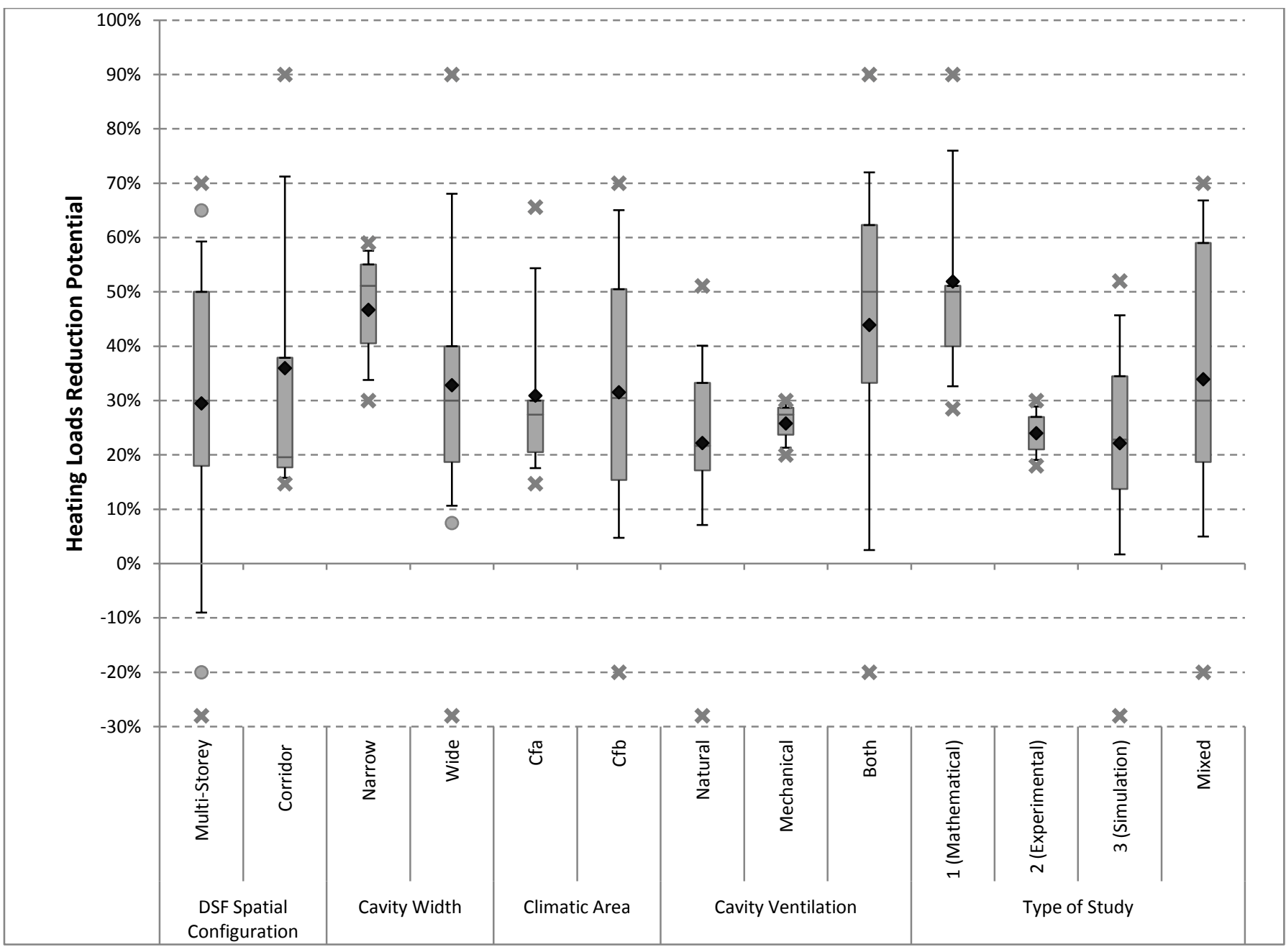

Figure 6 - Heating Loads Reduction Potential - Box and Whiskers Plot

\subsection{Cooling Loads}

Figure 7 shows the box and whiskers plots for cooling loads reduction potential.

According to these plots, cooling loads present more condensed and consistent figures. The plots show that there are no outliers in any of the clustering dimension, and the interquartile range is consistent across all. The results from mechanically ventilated cavities are very condensed compared to their naturally ventilated counterparts and a combination of the two strategies seems to promise higher energy savings. Similar to what was observed for heating loads, DSFs showed adverse effects on cooling loads as well, and simulation proved the only effective approach to point this out. Likewise, multi-storey and wide cavities seem to be characterised by a greater range of variation and, this could be attributed to a combined use with natural ventilation strategies which generally bear a higher variability of the operational behaviour of a DSF. 


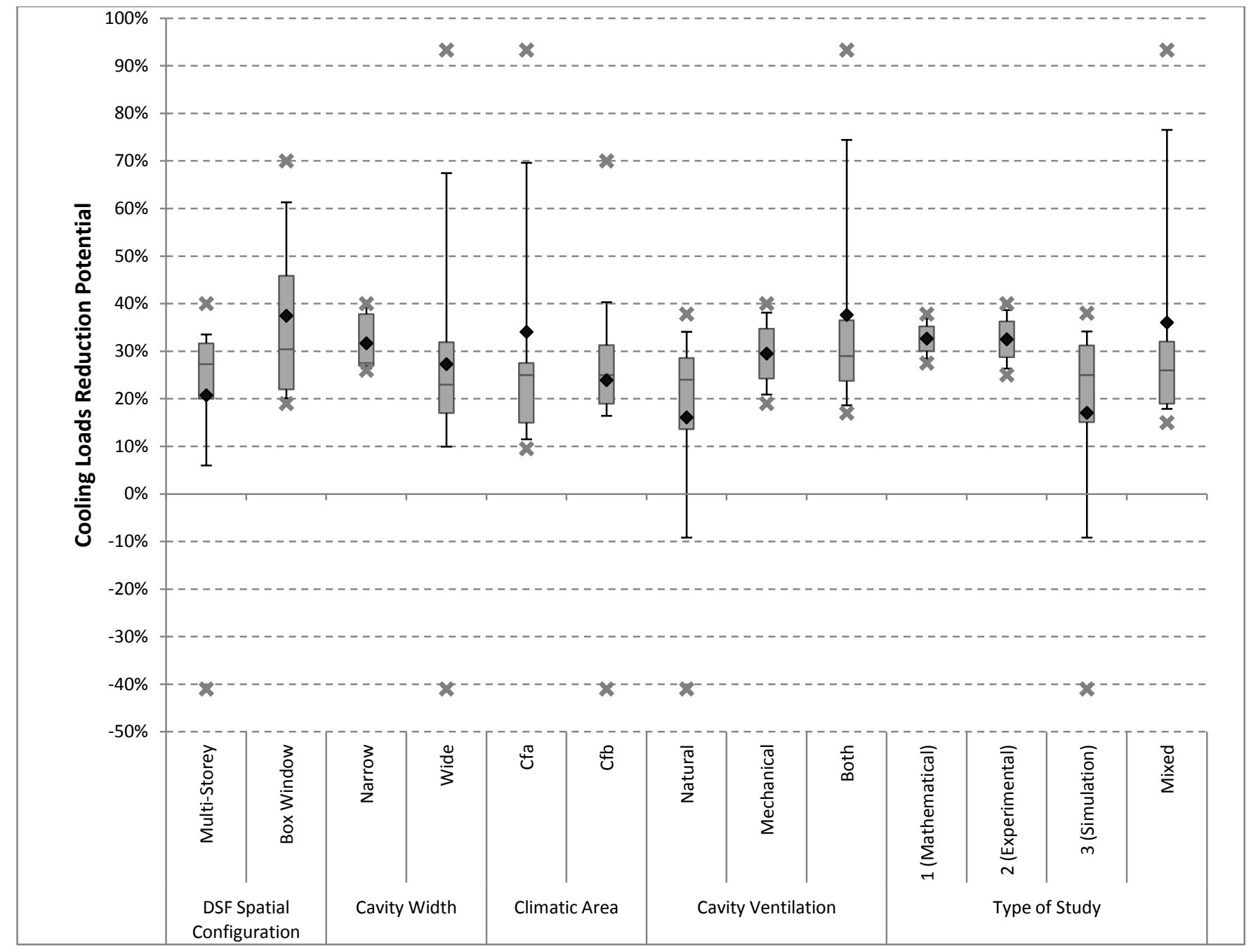

Figure 7 - Cooling Loads Reduction Potential - Box and Whiskers plot

\section{Conclusions}

This paper has reviewed energy performances related to double skin façades (DSFs) in temperate climates. Both embodied and operational energy figures have been considered, although very little information was found on the former. Regarding operational energy, four energy end-uses have been considered, i.e. (1) heating, (2) cooling, (3) lighting, and (4) ventilation. Key parameters such as the spatial configuration of the DSF, the cavity width and ventilation, the orientation, the climatic zone according to the Köppen-Geiger classification, and the type of study have all been considered, reviewed, and used as clustering criteria. Numerical results from the studies considered, have been normalised in the form of a percentage. Normalised data have then been reported in form of box and whiskers plots for the criteria considered in the two cases for which enough information was available, namely heating and cooling loads. A fair few concluding remarks can be summarised from this review as follows:

(1) The vast majority of existing DSF studies focus on operational energy. Embodied energy figures and, more specifically, life cycle assessment of DSFs should be urgently considered by scholars and practitioners alike. This is because environmental benefits and consequently sustainability of DSF technologies can only be strictly substantiated once augmented impacts of embodied energy pertaining to all life cycle stages are accounted for.

(2) Amongst the operational energy end-uses here considered, lighting and to some extent ventilation are the least considered in literature. While ventilation is very often linked to cooling studies, lighting and more specifically daylighting represent an interesting avenue for further research. 
(3) Recently, there has been a growing tendency to apply DSFs in refurbishment, and existing studies cover a broad variation of buildings type. Given that a DSF in refurbishment can combine the benefits of operational energy savings with those of reduced environmental impacts related to demolition and reconstruction, such applications require more investigations; more specifically in developed countries where the existing building stock gets replaced at a very slow pace of about $1 \%$ per year.

(4) Normalised results in terms of heating and cooling loads reduction show broad range of variations, i.e. in both cases, from $90 \%$ of energy reduction potential down to an adverse increment of $30 \%$ or more. Some classifying criteria emerged from the literature review as mainly responsible for that significant variation; those such as DSF spatial configuration (a), cavity width (b) and its ventilation (c), climatic zone (d), and the methodological approach to the study (e).

(5) Numerical findings from the literature reviewed for this study have been normalised and clustered around the aforementioned criteria. The box and whiskers plots have been chosen to present research findings. They helped identify existing trends and areas for further research. For instance, some categories such as wide cavities and multi-storey spatial configurations show a higher variability than the others. Although some educated speculations have been made within this paper as to why results appear that way, such speculation do not substitute more robust, in-depth, and systematic investigations.

(6) Results related to reduction of cooling loads deviate less than those of heating loads. With reference to a single clustering criterion, similar trends can be observed for experimental studies, mechanically ventilated cavities, and narrow cavities. In all these three clusters, normalised results show a smaller range of variation than their counterparts.

(7) Simulation seems to be a reliable and valid approach to modelling and studying DSFs. In both heating and cooling load scenarios simulation slightly underestimates experimental results, thus representing a 'safe' approach. Additionally, and again in both cases, it has been through simulations that the adverse effects on energy consumption could be identified and assessed.

\section{References}

[1] M.K. Dixit, J.L. Fernandez-Solis, S. Lavy, C.H. Culp, Need for an embodied energy measurement protocol for buildings: A review paper, Renewable \& Sustainable Energy Reviews, 16 (6) (2012) 3730-3743.

[2] IEA, Technology Roadmap. Energy efficient building envelopes, in, International Energy Agency, Paris, France, 2014.

[3] M.A. Shameri, M.A. Alghoul, K. Sopian, M.F.M. Zain, O. Elayeb, Perspectives of double skin facade systems in buildings and energy saving, Renewable \& Sustainable Energy Reviews, 15 (3) (2011) 1468-1475.

[4] V. Gavan, M. Woloszyn, F. Kuznik, J.-J. Roux, Experimental study of a mechanically ventilated double-skin facade with venetian sun-shading device: A full-scale investigation in controlled environment, Solar Energy, 84 (2) (2010).

[5] F. Kuznik, T. Catalina, L. Gauzere, M. Woloszyn, J.-J. Roux, Numerical modelling of combined heat transfers in a double skin facade - Full-scale laboratory experiment validation, Applied Thermal Engineering, 31 (14-15) (2011).

[6] E. Gratia, A. De Herde, The most efficient position of shading devices in a double-skin facade, Energy and Buildings, 39 (3) (2007).

[7] W.J. Stec, A.H.C. van Paassen, A. Maziarz, Modelling the double skin facade with plants, Energy and Buildings, 37 (5) (2005).

[8] M. Haase, A. Amato, Simplified Convective Heat Transfer in Vertical Airflow Regimes with Shading Device, Diffusion and Defect Data Part A: Defect and Diffusion Forum, 312 (1) (2011) 665-670.

[9] T.E. Jiru, Y.-X. Tao, F. Haghighat, Airflow and heat transfer in double skin facades, Energy and Buildings, 43 (10) (2011).

[10] W. Pasut, M. De Carli, Evaluation of various CFD modelling strategies in predicting airflow and temperature in a naturally ventilated double skin facade, Applied Thermal Engineering, 37 (2012). 
[11] N. Safer, M. Woloszyn, J.J. Roux, Three-dimensional simulation with a CFD tool of the airflow phenomena in single floor double-skin facade equipped with a venetian blind, Solar Energy, 79 (2) (2005).

[12] J. Darkwa, Y. Li, D.H.C. Chow, Heat transfer and air movement behaviour in a double-skin façade, Sustainable 1 Cities and Society, (0) (2013).

2

[13] C.L. Chow, NUMERICAL STUDIES ON SMOKE SPREAD IN THE CAVITY OF A DOUBLE-SKIN FACADE, Journal of Civil Engineering and Management, 17 (3) (2011).

[14] W.K. Chow, W.Y. Hung, Effect of cavity depth on smoke spreading of double-skin facade, Building and Environment, 41 (7) (2006).

[15] W.K. Chow, W.Y. Hung, Y. Gao, G. Zou, H. Dong, Experimental study on smoke movement leading to glass damages in double-skinned facade, Construction and Building Materials, 21 (3) (2007).

[16] W. Ding, Y. Hasemi, Ashrae, Smoke control through a double-skin facade used for natural ventilation, 2006.

[17] Z. Ni, S. Lu, L. Peng, Experimental study on fire performance of double-skin glass facades, Journal of Fire Sciences, 30 (5) (2012).

[18] W.T. Ding, Y.J. Hasemi, T. Yamada, Natural ventilation performance of a double-skin facade with a solar chimney, Energy and Buildings, 37 (4) (2005) 411-418.

[19] Y. Ji, M.J. Cook, V. Hanby, D.G. Infield, D.L. Loveday, L. Mei, CFD modelling of naturally ventilated double-skin facades with Venetian blinds, Journal of Building Performance Simulation, 1 (3) (2008) 185-196.

[20] Y. Takemasa, M. Hiraoka, M. Katoh, K. Miura, S. Kasai, T. Oya, Natural Ventilation with Dynamic Facades, International Journal of Ventilation, 8 (3) (2009).

[21] X.-I. Xu, Z. Yang, Natural ventilation in the double skin facade with venetian blind, Energy and Buildings, 40 (8) (2008).

[22] C.S. Park, G. Augenbroe, N. Sadegh, M. Thitisawat, T. Messadi, Real-time optimization of a double-skin facade based on lumped modeling and occupant preference, Building and Environment, 39 (8) (2004).

[23] S. Barbosa, K. Ip, Perspectives of double skin façades for naturally ventilated buildings: A review, Renewable and Sustainable Energy Reviews, 40 (0) (2014) 1019-1029.

[24] A. De Gracia, A. Castell, L. Navarro, E. Oró, L.F. Cabeza, Numerical modelling of ventilated facades: A review, Renewable and Sustainable Energy Reviews, 22 (0) (2013) 539-549.

[25] J. Zhou, Y. Chen, A review on applying ventilated double-skin facade to buildings in hot-summer and cold-winter zone in China, Renewable \& Sustainable Energy Reviews, 14 (4) (2010).

[26] G. Quesada, D. Rousse, Y. Dutil, M. Badache, S. Hallé, A comprehensive review of solar facades. Transparent and translucent solar facades, Renewable and Sustainable Energy Reviews, 16 (5) (2012) 2643-2651.

[27] L.F. Cabeza, L. Rincón, V. Vilariño, G. Pérez, A. Castell, Life cycle assessment (LCA) and life cycle energy analysis (LCEA) of buildings and the building sector: A review, Renewable and Sustainable Energy Reviews, 29 (0) (2014) 394416.

[28] T. Ibn-Mohammed, R. Greenough, S. Taylor, L. Ozawa-Meida, A. Acquaye, Operational vs. embodied emissions in buildings-A review of current trends, Energy and Buildings, 66 (0) (2013) 232-245.

[29] A.M. Moncaster, K.E. Symons, A method and tool for 'cradle to grave' embodied carbon and energy impacts of UK buildings in compliance with the new TC350 standards, Energy and Buildings, 66 (1) (2013).

[30] L. Gustavsson, A. Joelsson, Life cycle primary energy analysis of residential buildings, Energy and Buildings, 42 (2) (2010) 210-220.

[31] M.C. Peel, B.L. Finlayson, T.A. McMahon, Updated world map of the Köppen-Geiger climate classification, Hydrology and earth system sciences discussions, 4 (2) (2007) 439-473.

[32] M. Buyle, J. Braet, A. Audenaert, Life cycle assessment in the construction sector: A review, Renewable and Sustainable Energy Reviews, 26 (0) (2013) 379-388. 
[33] A. Compagno, Intelligent Glass Façades. Material - Practice - Design, Birkhäuser - Publishers for Architecture, Germany, 1999.

[34] E. Oesterle, R. Lieb, M. Lutz, W. Heusler, Double-Skin Facades. Integrated Planning, Prestel, Munich - London 1 New York, 2001.

2

[35] K. Roth, T. Lawrence, J. Brodrick, Double-skin facades, Ashrae Journal, 49 (10) (2007).

[36] J. Claessens, A. De Herde, Active Solar Heating and Photovoltaics. Solar Energy in European Office Buildings. , in, Energy Research Group, School of Architecture, University College of Dublin, Ireland, 2006.

[37] S. Brunoro, An assessment of energetic efficiency improvement of existing building envelopes in Italy, Management of Environmental Quality: An International Journal, 19 (6) (2008) 718-730.

[38] H. Poirazis, Double Skin Facades for Office Buildings - Literature Review, in: Report EBD-R--04/3, Lund University - Institute of Technology - Department of Construction and Architecture - Division of Energy and Building Design, Lund, 2004.

[39] BBRI, Source book for a better understanding of conceptual and operational aspects of active facades. Department of Building Physics, Indoor Climate and Building Services, Version n. 1, in, Belgian Building Research Institute, 2002.

[40] D. Saelens, J. Carmeliet, H. Hens, Energy Performance Assessment of Multiple-Skin Facades, HVAC\&R Research, 9 (2) (2003) 167-185.

[41] X. Loncour, A. Deneyer, M. Blasco, G. Flamant, P. Wouters, Ventilated Double Facades. Classification \& Illustration of Facade Contepts, in, BBRI (Belgian Building Research Institute). Department of Building Physics, Indoor Climate \& Building Services, 2004.

[42] M. Haase, F.M. da Silva, A. Amato, Simulation of ventilated facades in hot and humid climates, Energy and Buildings, 41 (4) (2009).

[43] E. Gratia, A. De Herde, Natural ventilation in a double-skin facade, Energy and Buildings, 36 (2) (2004).

[44] R. Høseggen, B.J. Wachenfeldt, S.O. Hanssen, Building simulation as an assisting tool in decision making - Case study: With or without a double-skin facade?, Energy and Buildings, 40 (5) (2008).

[45] P.R. Diprose, G. Robertson, Towards a fourth skin? Sustainability and double-envelope buildings, Renewable Energy, 8 (1-4) (1996) 169-172.

[46] G. Wadel, P. Alonso, J.-L. Zamora, P. Garrido, Simplified LCA in skin design: The FB720 case, International Journal of Sustainable Building Technology and Urban Development, 4 (1) (2013) 68-81.

[47] A. de Gracia, L. Navarro, A. Castell, D. Boer, L.F. Cabeza, Life cycle assessment of a ventilated facade with PCM in its air chamber, Solar Energy, (0) (2013).

[48] M. Kolokotroni, S. Robinson-Gayle, S. Tanno, A. Cripps, Environmental impact analysis for typical office facades, Building Research \& Information, 32 (1) (2004) 2-16.

[49] C. Scheuer, G.A. Keoleian, P. Reppe, Life cycle energy and environmental performance of a new university building: modeling challenges and design implications, Energy and Buildings, 35 (10) (2003) 1049-1064.

[50] L.G.F. Tellnes, L.R. Gobakken, P.O. Flæte, G. Alfredsen, Carbon footprint including effect of carbon storage for selected wooden facade materials, Wood Material Science \& Engineering, 9 (3) (2014) 139-143.

[51] I. Perez-Grande, J. Meseguer, G. Alonso, Influence of glass properties on the performance of double-glazed facades, Applied Thermal Engineering, 25 (17-18) (2005).

[52] G. Baldinelli, Double skin facades for warm climate regions: Analysis of a solution with an integrated movable shading system, Building and Environment, 44 (6) (2009).

[53] M. Wigginton, B. McCarthy, 'The Environmental Second Skin' - Research carried out for the UK Department of the Environment Transport and the Regions, 2000.

[54] A. Pappas, Energy Performance of a DSF - Analysis for the Museum of Contemporary Art, Denver, in: SOLAR 2006, Denver USA, 2006. 
[55] A.S. Andjelkovic, T.B. Cvjetkovic, D.D. Djakovic, I.H. Stojanovic, DEVELOPMENT OF SIMPLE CALCULATION MODEL FOR ENERGY PERFORMANCE OF DOUBLE SKIN FACADES, Thermal Science, 16 (2012).

[56] W. Choi, J. Joe, Y. Kwak, J.-H. Huh, Operation and control strategies for multi-storey double skin facades during 1 the heating season, Energy and Buildings, 49 (2012).

2

[57] H. Ghadamian, M. Ghadimi, M. Shakouri, M. Moghadasi, M. Moghadasi, Analytical solution for energy modeling of double skin façades building, Energy and Buildings, 50 (1-2) (2012) 158-165.

[58] E. Gratia, A. De Herde, Optimal operation of a south double-skin facade, Energy and Buildings, 36 (1) (2004).

[59] J. Blumenberg, M. Spinnler, T. Sattelmayer, Double-skin façade systems - A comprehensive review on thermal and energetic behavior, in: International Conference on "Recent Advances in Heat Transfer", Karunya Institute of Technology and Sciences, Coimbatore, India, 2006.

[60] A. Fallahi, F. Haghighat, H. Elsadi, Energy performance assessment of double-skin facade with thermal mass, Energy and Buildings, 42 (9) (2010).

[61] G. Kim, L.A. Schaefer, J.T. Kim, Development of a Double-Skin Facade for Sustainable Renovation of Old Residential Buildings, Indoor and Built Environment, 22 (1) (2013) 180-190.

[62] I. Cakmanus, Optimization of Double Skin Facades for Buildings: An Office Building Example In Ankara-Turkey, in: Proceedings of Clima 2007 WellBeing Indoors, Helsinki, June 10-14, 2007.

[63] L. Xu, T. Ojima, Field experiments on natural energy utilization in a residential house with a double skin facade system, Building and Environment, 42 (5) (2007).

[64] Z. Yılmaz, F. Çetintaş, Double skin façade's effects on heat losses of office buildings in Istanbul, Energy and Buildings, 37 (7) (2005) 691-697.

[65] S.K. Chou, K.J. Chua, J.C. Ho, A study on the effects of double skin facades on the energy management in buildings, Energy Conversion and Management, 50 (9) (2009).

[66] I. Cetiner, E. Ozkan, An approach for the evaluation of energy and cost efficiency of glass facades, Energy and Buildings, 37 (6) (2005).

[67] D. Arons, Properties and Applications of Double-Skin Building Facades, Building Technology, Massachusetts Institute of Technology (MIT), 2000.

[68] M. Kragh, Monitoring of Advanced Facades and Environmental Systems, in: The whole-life performance of facades, University of Bath, CWCT, 18/19 April, 2001.

[69] M. Kragh, Facade Engineering and Building Physics. Examples of current best practice and recent innovations, in: Integrated Facade Symposium, San Francisco. 21 April, 2010.

[70] E. Gratia, A. De Herde, Are energy consumptions decreased with the addition of a double-skin?, Energy and Buildings, 39 (5) (2007).

[71] Y.-M. Kim, J.-H. Lee, S.-M. Kim, S. Kim, Effects of double skin envelopes on natural ventilation and heating loads in office buildings, Energy and Buildings, 43 (9) (2011).

[72] G. Ballestini, M. De Carli, N. Masiero, G. Tombola, Possibilities and limitations of natural ventilation in restored industrial archaeology buildings with a double-skin facade in Mediterranean climates, Building and Environment, 40 (7) (2005).

[73] T. Pasquay, Natural ventilation in high-rise buildings with double facades, saving or waste of energy, Energy and Buildings, 36 (4) (2004) 381-389.

[74] Y.-M. Kim, S.-Y. Kim, S.-W. Shin, J.-Y. Sohn, Contribution of natural ventilation in a double skin envelope to heating load reduction in winter, Building and Environment, 44 (11) (2009) 2236-2244.

[75] S.C. Zerefos, On the performance of double skin facades in different environmental conditions, International Journal of Sustainable Energy, 26 (4) (2007) 221-229.

[76] D. Saelens, S. Roels, H. Hens, Strategies to improve the energy performance of multiple-skin facades, Building and Environment, 43 (4) (2008). 
[77] N. Papadaki, S. Papantoniou, D. Kolokotsa, A parametric study of the energy performance of double-skin façades in climatic conditions of Crete, Greece, International Journal of Low-Carbon Technologies, (2013).

[78] W.J. Stec, A.H.C. van Paassen, Symbiosis of the double skin facade with the HVAC system, Energy and Buildings, 137 (5) (2005).

2

[79] C. Balocco, A simple model to study ventilated facades energy performance, Energy and Buildings, 34 (5) (2002) 469-475.

[80] D. Faggembauu, M. Costa, M. Soria, A. Oliva, Numerical analysis of the thermal behaviour of glazed ventilated facades in Mediterranean climates. Part II: applications and analysis of results, Solar Energy, 75 (3) (2003) 229-239.

[81] H. Tanaka, M. Okumiya, H. Tanaka, G.Y. Yoon, K. Watanabe, Thermal characteristics of a double-glazed external wall system with roll screen in cooling season, Building and Environment, 44 (7) (2009).

[82] E. Gratia, A. De Herde, Natural cooling strategies efficiency in an office building with a double-skin facade, Energy and Buildings, 36 (11) (2004).

[83] J. Hensen, M. Bartak, F. Drkal, Modeling and Simulation of Double-Skin Facade System, ASHRAE Transactions, 108 (2) (2002) 1251-1259.

[84] N. Mingotti, T. Chenvidyakarn, A.W. Woods, The fluid mechanics of the natural ventilation of a narrow-cavity double-skin facade, Building and Environment, 46 (4) (2011).

[85] A. Reith, A. Gelesz, G. Pueltz, Evaluation and optimization of a double skin facade with the help of computational simulations, Bauphysik, 33 (2) (2011).

[86] V. Huckemann, E. Kuchen, M. Leao, E.F.T.B. Leao, Empirical thermal comfort evaluation of single and double skin facades, Building and Environment, 45 (4) (2010).

[87] A. Viljoen, J. Dubiel, M. Wilson, M. Fontoynont, Investigations for improving the daylighting potential of doubleskinned office buildings, Solar Energy, 59 (4-6) (1997).

[88] M.A. Shameri, M.A. Alghoul, O. Elayeb, M.F.M. Zain, M.S. Alrubaih, H. Amir, K. Sopian, Daylighting characterstics of existing double-skin façade office buildings, Energy and Buildings, 59 (0) (2013) 279-286.

[89] W. Lang, T. Herzog, Using multiple glass skins to clad buildings, Architectural Record, 7 (2000) 171-182.

[90] E. Gratia, A. De Herde, Is day natural ventilation still possible in office buildings with a double-skin façade?, Building and Environment, 39 (4) (2004) 399-409.

[91] E. Gratia, A. De Herde, Guidelines for improving natural daytime ventilation in an office building with a doubleskin facade, Solar Energy, 81 (4) (2007).

[92] D. Saelens, S. Roels, H. Hens, The inlet temperature as a boundary condition for multiple-skin facade modelling, Energy and Buildings, 36 (8) (2004).

[93] F. Asdrubali, G. Baldinelli, F. D’Alessandro, F. Scrucca, Life cycle assessment of electricity production from renewable energies: Review and results harmonization, Renewable and Sustainable Energy Reviews, 42 (0) (2015) $1113-1122$. 